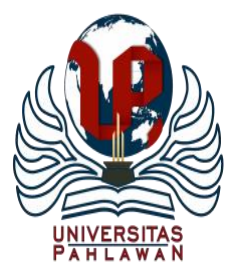

Jurnal Abdidas Volume 2 Nomor 1 Tahun 2021 Halaman 148-156

JURNAL ABDIDAS

http://abdidas.org/index.php/abdidas

\title{
Pelatihan Pengelolaan Keuangan bagi Ibu PKK Bintara Jaya, Bekasi Barat
}

\author{
Triana Yuniati $^{1}$, Murti Wijayanti ${ }^{2}$, Tutiek Yoganingsih ${ }^{3}$, Budi Indrawati ${ }^{4}$ \\ Fakultas Ekonomi dan Bisnis, Universitas Bhayangkara Jakarta Raya, Indonesia ${ }^{1,2,3,4}$ \\ E-mail: trianayuniati@ymail.com ${ }^{1}$, murti.wijayanti@dsn.ubharajaya.ac.id ${ }^{2}$, tutiekyn@ @mail.com ${ }^{3}$, \\ budi.indrawati@dsn.ubharajaya.ac.id ${ }^{4}$
}

\begin{abstract}
Abstrak
Aktivitas perencanaan dan pengelolaan keuangan dalam lingkup keluarga umumnya dikoordinir oleh ibu yang berprofesi sebagai manajer keuangan dalam rumah tangga. Kelompok ibu ini dituntut berwawasan pengetahuan dalam hal literasi keuangan dan bekerjasama dengan pasangan serta anggota keluarga intinya untuk mewujudkan kesejahteraan dan kestabilan ekonomi keluarga. Permasalahan yang kerap muncul pada umumnya adalah ketidakcermatan dalam pola mengatur dana pemasukan, serta mengalokasikan pengeluarannya ke berbagai tujuan yang telah direncanakan sebelumnya, maupun yang bersifat taktis. Melalui kegiatan pengabdian kepada masyarakat yang dilaksanakan dalam bentuk edukasi pelatihan perencanaan dan pengelolaan keuangan sederhana menggunakan simulasi kertas kerja penilaian, pemaparan teori dan sesi diskusi tanya jawab berbagi pengalaman dari kelompok Ibu-ibu rumah tangga di PKK RW.014, Kelurahan Bintara Jaya, Kecamatan Bekasi Barat, dicapai tingkat pemahaman peserta dalam hal memberikan keputusan alokasi dana tepat yang dimiliki ke beberapa pos pengeluaran, mengurangi pengeluaran berdasarkan pemilihan kriteria kebutuhan (needs) dan keinginan (wants), melakukan alternatif kegiatan investasi pada instrumen keuangan yang tepat untuk persiapan memasuki masa pensiun, serta mendorong adanya gagasan dan peluang baru peningkatan penghasilan keluarga dengan berwirausaha.
\end{abstract}

Kata kunci: kebutuhan, keinginan, kesejahteraan, literasi keuangan

\section{Abstract}

Within scope of the family, the planning and financial management activities are generally coordinated by a mother who works as a household financial manager. These groups of mothers are required to have knowledgeable of financial literacy and work together with their partners and their immediate family members to achieve family welfare and economic stability. Generally, the problem that often arises is the inaccurate pattern of managing income and allocating their expenditure of funds to various objectives, both those were planned in advance and occured tactically. Through this community service activity program which is carried out in the simple form educational training of planning and financial management by using a simulation working papers assessment, theory presentation and discussion sessions of sharing experiences from a group of housewives in PKK RW.014 Bintara Jaya Village, West Bekasi District, the level of understanding achieved by the participants such in terms of making the right decisions for allocating funds to several expenditure items, reducing unnecessary spending of funds based on selecting criteria for needs and wants, making alternative investment activities for retirement preparation, and encouraging new ideas and opportunities to increase family income through entrepreneurship.

Keywords: financial literacy, needs, wants, welfare

Copyright (c) 2021 Triana Yuniati, Murti Wijayanti, Tutiek Yoganingsih, Budi Indrawati

$\triangle$ Corresponding author:

Address : Universitas Bhayangkara Jakarta Raya

ISSN 2721- 9224 (Media Cetak)

Email : murti.wijayanti@dsn.ubharajaya.ac.id

DOI $:$ https://doi.org/10.31004/abdidas.v2i1.234

ISSN 2721- 9216 (Media Online) 
149 Pelatihan Pengelolaan Keuangan bagi Ibu PKK Kelurahan Bintara Jaya, Bekasi Barat- Triana Yuniati, Murti Wijayanti, Tutiek Yoganingsih, Budi Indrawati

DOI: https://doi.org/10.31004/abdidas.v2i1.234

\section{PENDAHULUAN}

Peran seorang ibu dalam kehidupan berumah tangga memiliki andil besar mengantarkan kesejahteraan keluarga intinya. Salah satu ukuran kesejahteraan dalam lingkup keluarga dikaitkan dengan faktor keuangan (finansial). Lingkup keluarga dapat diasosiasikan sebagai perusahaan yang membutuhkan perencanaan dan pengelolaan keuangan antara penghasilan yang diperoleh baik dari suami ataupun dari hasil usaha istri dengan pengeluaran yang terjadi dalam bentuk tabungan, konsumsi maupun investasi. Umumnya, aktivitas tersebut mayoritas dikendalikan oleh istri sebagai manajer keuangan dalam keluarga (kompasiana.com). Tentunya, diperlukan kerjasama yang baik dengan suami sebagai pemberi nafkah, di samping harus memiliki pengetahuan dan keahlian diri guna mewujudkan kesejahteraan dan kestabilan ekonomi keluarga.

Masalah keuangan yang terjadi dan dihadapi seseorang dalam menjalankan aktivitas pengelolaan keuangan, mendorong dibutuhkannya literasi keuangan. Bahkan di beberapa negara maju sudah dicanangkan menjadi program nasional. Riset secara umum menunjukkan bahwa tingkat literasi keuangan yang rendah di negara-negara maju masih terjadi, terlebih lagi di negara-negara sedang berkembang termasuk Indonesia (Yushita, 2017).

Ketidaktepatan dalam mengelola keuangan rumah tangga menjadi masalah yang harus dihadapi dan diselesaikan bersama dengan melakukan diskusi dan evaluasi atas kebutuhan dan keinginan yang muncul dari para anggota keluarga lainnya. Keputusan untuk melakukan penghematan atau inisiatif menyisihkan sejumlah dana untuk cadangan darurat maupun kebutuhan investasi merupakan hal yang perlu disepakati bersama. Disinilah para ibu dituntut untuk memiliki wawasan dan pengalaman luas agar perencanaan dan pengelolaan keuangannya benar, efektif, dan tepat sasaran. Beberapa penelitian juga dilakukan untuk menguji adanya keterkaitan antara tingkat literasi keuangan dengan pola alokasi pendapatan pada ibu rumah tangga yang bekerja dan tidak bekerja (Hidayah, 2018).

Faktor keuangan akan menjadi suatu problematika bagi siapapun yang melakukan ketidaktepatan pengalokasian dana sehubungan dengan aktivitas kegiatan yang melibatkan mata uang. Pengaturan dan pengelolaan keuangan kerap kali menjadi tantangan karena harus cermat dalam skala prioritas yang membagi pemasukan ke pospos pengeluaran kebutuhan utama (primer), kebutuhan sampingan (sekunder) dan investasi.

Pemerintah melalui Otoritas Jasa Keuangan (OJK) mensosialisasikan literasi dan inklusi keuangan yang bertujuan meningkatkan pemahaman masyarakat Indonesia tentang dasardasar pengelolaan keuangan dan pentingnya pengelolaan keuangan yang baik, mencakup menabung dan investasi, pengenalan berbagai produk dan instrumen keuangan termasuk risiko dan imbal hasil produk keuangan, serta literasi hak-hak konsumen. Menurut OJK, pengetahuan yang baik tentang keuangan menjadi kunci peningkatan kesejahteraan masyarakat secara makro dan dalam jangka panjang dapat menggerakkan roda perekonomian nasional 
150 Pelatihan Pengelolaan Keuangan bagi Ibu PKK Kelurahan Bintara Jaya, Bekasi Barat- Triana Yuniati, Murti Wijayanti, Tutiek Yoganingsih, Budi Indrawati

DOI: https://doi.org/10.31004/abdidas.v2i1.234

(Media Indonesia, 26 Agustus 2019). Memasuki semester 2 tahun 2020, pemerintah Indonesia menerbitkan obligasi negara retail (ORI) seri 017. Informasi yang diperoleh dari market.bisnis.com, penerbitan kali ini mendorong daya pikat ibu rumah tangga sebagai investor yang persentase kepemilikannya mencapai 13,1 persen. Hal tersebut mengindikasikan bahwa kalangan ibu rumah tangga mulai tergerak tidak cukup hanya menabung, tapi mulai melirik berinvestasi dalam instrumen keuangan negara.

Pelaksanaan acara ini dikemas dalam bentuk pelatihan yang bertemakan pengelolaan keuangan sederhana, selain sebagai salah satu wujud Tri Dharma kepada masyarakat ibu rumah tangga kelompok PKK RW. 014 Kelurahan Bintara Jaya, Kecamatan Bekasi Barat, bertujuan untuk:

1. Membuka wawasan dan pengetahuan tentang bagaimana mengelola keuangan keluarga secara sederhana dan tepat sasaran.

2. Membantu pengelolaan keuangan dengan melakukan trial (uji percobaan) simulasi pada modul pelatihan keuangan sederhana.

3. Memberdayakan ibu sebagai manajer keuangan keluarga dengan melakukan sosialisasi berinvestasi pada instrumen keuangan yang aman dan tepat, meningkatkan pemasukan pendapatan dengan peluang berwirausaha, serta pemilihan jenis investasi persiapan memasuki masa pensiun.

4. Menciptakan gaya hidup mengelola dan mengendalikan keuangan yang lebih cermat agar terhindar dari pengeluaran yang tidak perlu berdasarkan keputusan kriteria needs and wants.

\section{METODE}

Pelaksanaan kegiatan pengabdian masyarakat ini pada awalnya dilakukan observasi dan wawancara langsung untuk mengetahui situasi permasalahan yang dihadapi di lingkungan masyarakat. Perkembangan teknologi selama beberapa tahun akhir menjadikan daya beli masyarakat meningkat dibarengi pula dengan pola konsumtifnya. Berangkat dari kondisi tersebut, disepakati diadakan pelatihan dengan tema pengelolaan keuangan sederhana, dimana kegiatan tersebut dikemas sedemikian rupa sehingga peserta sebelum melakukan pelatihan akan digali terlebih dahulu kebiasaannya dalam mengelola keuangan, kemudian dianalisa apakah kebiasaannya tersebut sudah tepat atau perlu adanya "terapi" dalam pelaksanaan pengelolaan keuangannya tersebut. Beberapa tips dari berbagai pakar, diadopsi dan dirangkum oleh tim narasumber sehingga menjadi materi bahan yang menarik untuk disampaikan dan didiskusikan berdasarkan pengalaman dan realita di lapangan (Senduk, 2009).

\section{Tahap Persiapan}

Setelah penentuan topik, berikut dilakukan koordinasi pembagian tugas antara tim narasumber dengan RW.014 dimana kelompok ibu PKK bernaung, antara lain: penetapan lokasi pelatihan di aula serbaguna; pengurusan administrasi surat menyurat, surat ijin, sertifikat; pencarian studi pustaka literatur untuk bahan materi peserta dan paparan; inventarisasi perlengkapan acara, seperti spanduk, proyektor infocus, konsumsi. 
151 Pelatihan Pengelolaan Keuangan bagi Ibu PKK Kelurahan Bintara Jaya, Bekasi Barat- Triana Yuniati, Murti Wijayanti, Tutiek Yoganingsih, Budi Indrawati

DOI: https://doi.org/10.31004/abdidas.v2i1.234

\section{Tahap Pelaksanaan}

Kegiatan acara dikemas dalam bentuk pelatihan langsung kepada peserta, dimana topik pengelolaan keuangan dari beberapa literatur sumber diadopsi dan dirumuskan menjadi booklet modul materi pelatihan yang dibagikan ke masingmasing peserta, dan dibuka oleh Ketua PKK RW. 014, Kelurahan Bintara Jaya Ibu Yeyen selaku pemangku hajat, dilanjutkan perkenalan tim narasumber oleh ketua PKM Universitas, Ibu Triana.

Berikut alur kegiatan pelatihan pada tahapan pelaksanaan.

\section{Pengisian Kuesioner}

Sebelum pelatihan dimulai, tim narasumber memberikan instruksi alur pelaksanaan pelatihan dan membagikan kuesioner sederhana kepada para peserta untuk mengisikan jawabannya antara 2 (dua) pilihan Benar (B) atau Salah (S) sebagai pemetaan awal peserta untuk mengetahui sejauh mana tingkat pengelolaan keuangan yang selama ini dijalani.

Tabel 1. Data Kuesioner

\begin{tabular}{|l|c|l|}
\hline \multicolumn{1}{|c|}{ Variabel } & \multicolumn{2}{c|}{ Indikator } \\
\hline Kebutuhan & 7 & Keharusan memiliki sesuatu \\
\hline Keinginan & 8 & Dana yang dikeluarkan \\
\hline Menabung & 10 & Perjuangan menabung \\
\hline
\end{tabular}

Bagian awal kuesioner diisikan identitas peserta, dilanjutkan dengan pertanyaan berdasarkan 3 (tiga) variabel kategori. Bagian A, terdiri dari 7 item pertanyaan terkait "kebutuhan" yang bersifat primer. Bagian B, terdiri dari 8 item pertanyaan terkait "keinginan" yang bersifat sekunder. Bagian C, terdiri dari 10 item pertanyaan terkait kegiatan "menabung”. Setelah ketiga bagian kuesioner pertanyaan tersebut terisi, pada tahap awal ini akan dilakukan peninjauan pada masingmasing peserta sebagai introspeksi untuk dilakukan analisa lebih lanjut menggunakan formula keseimbangan dana (The Balance Money Formula $)=5: 3: 2$.

\section{Formula Keseimbangan Dana (The Balance} Money Formula)

Hasil tinjauan awal pengisian kuesioner peserta, tim narasumber menganalisa hasil untuk dilakukan pembahasan lebih mendetail menggunakan alat bantu kertas kerja penilaian yang dikaitkan dengan literatur teori pengelolaan dana, sebelum memasuki teknis pelatihan.

Berawal dari paparan keluarga sebagai unit satuan terkecil dalam masyarakat, peran yang dimiliki oleh para anggota keluarga, hingga memasuki tahap konflik salah satunya adalah menghadapi kesulitan keuangan (Handayani, 2013). Solusi atas permasalahan ini dipetakan kembali dari awal mula munculnya teori manajemen keuangan yang merupakan suatu kegiatan dalam hal perencanaan, penganggaran, pemeriksaaan, pengelolaan, pengendalian, pencarian, dan penyimpanan dana yang dilakukan baik oleh individu maupun organisasi untuk mencapai tujuannya. Kegiatan tersebut berhubungan dengan 3 (tiga) aktivitas utama yaitu: 1) penggunaan dana; 2) perolehan dana; dan 3) pengelolaan aktiva.

Teori tentang manajemen keuangan dasar tersebut berkembang dan menghasilkan beberapa pendapat dari penulis lokal dan internasional untuk membantu mereka dalam pencapaian tujuannya. 
152 Pelatihan Pengelolaan Keuangan bagi Ibu PKK Kelurahan Bintara Jaya, Bekasi Barat- Triana Yuniati, Murti Wijayanti, Tutiek Yoganingsih, Budi Indrawati

DOI: https://doi.org/10.31004/abdidas.v2i1.234

Salah satu acuan yang digunakan adalah tulisan Elizabeth Warren dalam All Your Worth: The Ultimate Lifetime Money Plan (Warren \& Tyagi, 2006) yang mempopulerkan istilah Formula Keseimbangan Dana, dan teori tersebut membantu mereka yang kesulitan dalam mengelola keuangan harian. Formula keseimbangan tersebut (Gambar 1) dirumuskan menjadi kategori: $50 \%$ untuk "kebutuhan" (needs); 30\% untuk "keinginan" (wants); dan sisanya $20 \%$ untuk "menabung" (saving). Masing-masing kategori memiliki ukuran (score) berada di posisi mana kondisi pengelolaan keuangan saat ini. Untuk mengetahui posisi kategori tersebut, perlu dilakukan analisa simulasi keuangan dengan menggunakan bantuan Kertas Kerja (KK).

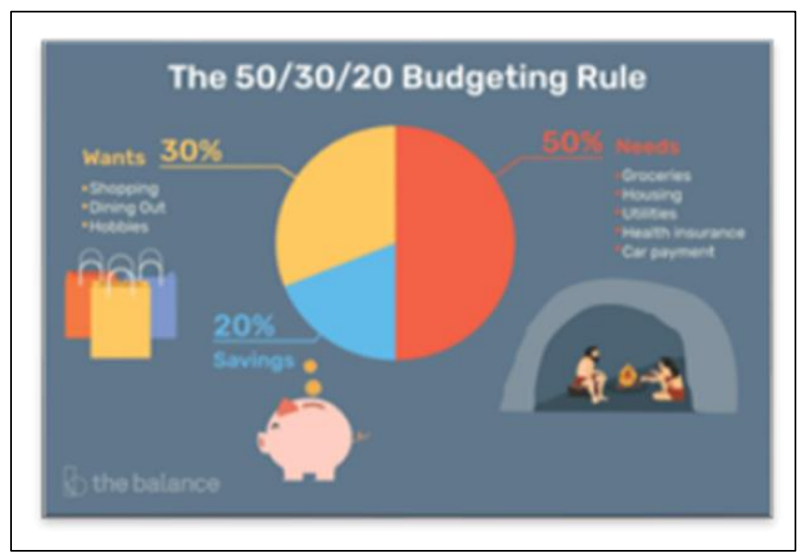

Gambar 1. Formula Keseimbangan Dana

Pengisian kertas kerja dalam bentuk nominal mata uang guna dilakukan penilaian yang lebih mendetail dan terdiri dari 4 (empat) bagian penilaian rinci terkait aktivitas pengelolaan keuangan berikut.

KK-1 (Penghasilan), diisikan nominal sumber pemasukan dana dalam rumah tangga bersifat tetap dan variabel. Total dari nominal dana penghasilan digunakan sebagai angka mutlak pembagi untuk menghitung skor pada KK-2 dan KK-3.

KK-2 (Kebutuhan), diisikan nominal pengeluaran dana bersifat primer termasuk di dalamnya kebutuhan tempat tinggal, kesehatan, transportasi, makanan, dan kebutuhan langganan lain bersifat wajib. Perolehan total nominal dana kebutuhan, dikonversikan dalam bentuk skor persentase dengan membagi angka perolehan KK1.

KK-3 (Menabung), diisikan nominal kontribusi dana yang dibayarkan kepada institusi lain dalam bentuk tabungan ataupun dana pensiun. Perolehan total nominal dana menabung, dikonversikan dalam bentuk skor persentase dengan membagi angka perolehan KK-1.

KK-4 (Keinginan), diisikan penjumlahan angka skor KK-2 dan KK-3 yang kemudian dikurangkan dari angka skor KK-1 untuk memperoleh angka skor keinginan yang menunjukkan bagian dari kebutuhan sekunder ataupun tersier dari aktivitas pengelolaan uang.

\section{Analisa Skor Keseimbangan}

Skor hasil akhir dari masing-masing KK penilaian kategori 1 sampai dengan 4, selanjutnya dilakukan pembandingan dengan angka yang tertera pada tabel formula keseimbangan dana (Gambar 2) untuk dilakukan "tinjauan lanjutan" atas kondisi pengelolaan keuangan saat ini. Artinya, pengeluaran yang dilakukan untuk belanja kebutuhan primer, sekunder, dan tabungan simpanan telah dialokasikan sesuai dengan formula keseimbangan dana. Apabila hasil skor 
153 Pelatihan Pengelolaan Keuangan bagi Ibu PKK Kelurahan Bintara Jaya, Bekasi Barat- Triana Yuniati, Murti Wijayanti, Tutiek Yoganingsih, Budi Indrawati

DOI: https://doi.org/10.31004/abdidas.v2i1.234

menunjukkan pada kondisi yang perlu dilakukan "treatment" penanganan atau pembenahan, maka perlu dibuat perencanaan keuangan dasar individu berdasarkan konsep rencana anggaran, pemangkasan biaya (kebutuhan vs keinginan), keluar dari utang, tabungan untuk pensiun dan ikut program asuransi.

Tabel pemetaan skor hasil analisa perhitungan menggunakan perangkat kertas kerja, terdiri dari 3 area bagian yang mewakili formula keseimbangan dana dari pola pengelolaan dana. Area merah menunjukkan kategori skor formula "kebutuhan" dengan komposisi 50\%, area kuning menunjukkan kategori skor formula "keinginan" dengan komposisi 30\%, dan area biru menunjukkan kategori skor formula "menabung" dengan komposisi $20 \%$.

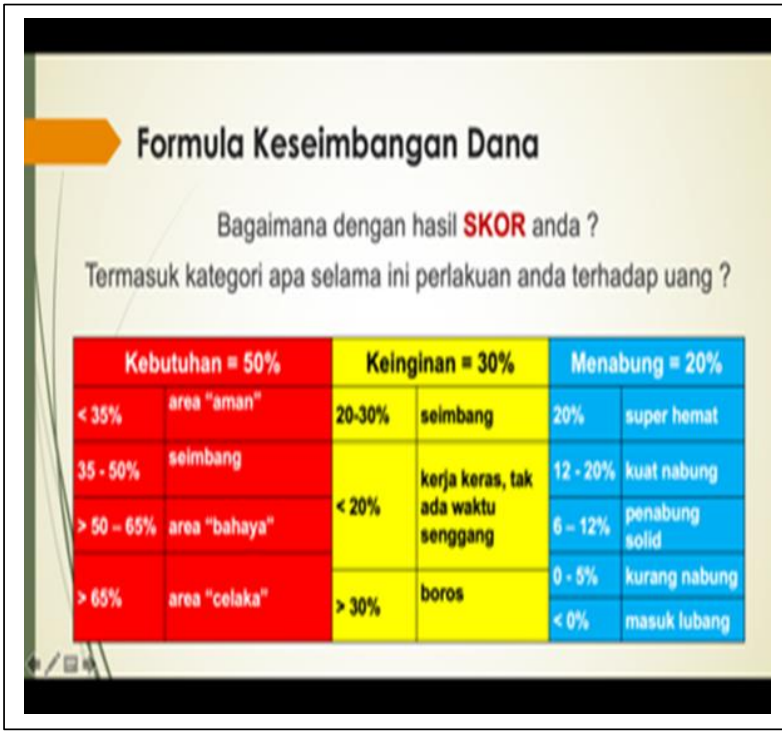

Gambar 2. Skor Formula Keseimbangan Dana

\section{Tahap Evaluasi}

Setelah dilakukan analisa skor keseimbangan dan peserta mengetahui kondisi perlakuan pengelolaan dana keuangannya berada dikategori tertentu, hal yang dilakukan berikut adalah melakukan analisa tinjauan kembali aktivitas pengelolaan dana, dengan membuat anggaran perencanaan. Minimal alokasi peruntukan dananya mendekati skor keseimbangan, bahkan menjadikan suatu gaya hidup pengelolaan dana yang lebih baik bagi kelompok ibu yang sudah imbang dan matang dalam aktivitas pengelolaan dananya.

\section{HASIL DAN PEMBAHASAN}

Pelatihan pengelolaan keuangan sederhana ini merupakan agenda kegiatan perdana bagi kelompok Ibu-ibu PKK RW.014 di masa transisi Pembatasan Sosial Berskala Besar (PSBB) pandemi Covid-19. Pelaksanaan acara pada hari Minggu, 8 November 2020, di area serbaguna RW.04, Perumahan Bintara Alam Permai dan diselenggarakan dengan protokol kesehatan yang ketat.

Kegiatan ini diikuti oleh 32 peserta (Gambar 3) dengan rentang kelompok usia >20-35 tahun $34,4 \%$; usia $>35-50$ tahun $53,1 \%$; dan usia $>50$ tahun $12,5 \%$. Ditilik dari segi pekerjaan, $84 \%$ peserta masih aktif bekerja baik sebagai pegawai instansi maupun ibu rumah tangga merangkap wirausaha dengan status menikah ada tanggungan sejumlah 69\%; lajang atau pernah menikah dan ada tanggungan sejumlah $31 \%$. Sisanya, $16 \%$ peserta adalah ibu rumah tangga yang memasuki usia non-produktif atau pensiun. 
154 Pelatihan Pengelolaan Keuangan bagi Ibu PKK Kelurahan Bintara Jaya, Bekasi Barat- Triana Yuniati, Murti Wijayanti, Tutiek Yoganingsih, Budi Indrawati

DOI: https://doi.org/10.31004/abdidas.v2i1.234

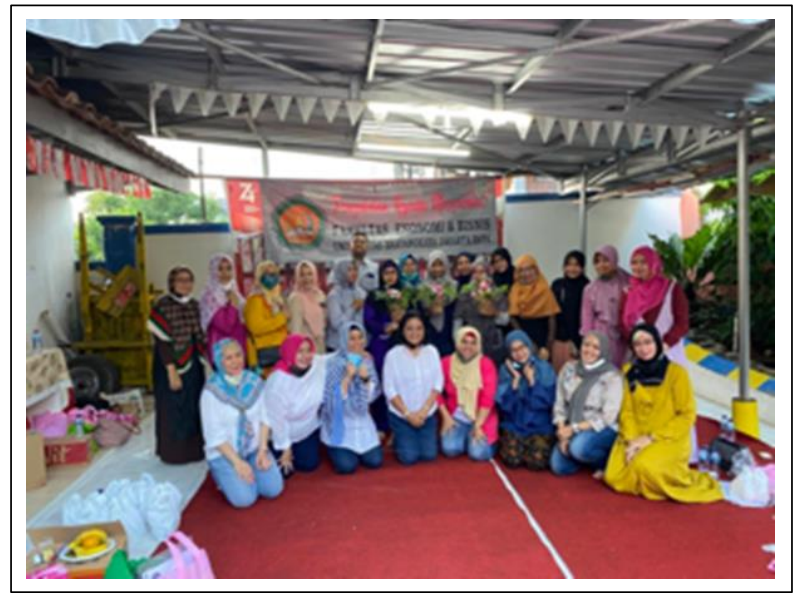

Gambar 3. Peserta dan Narasumber

Tahap pelaksanaan awal, tinjauan pemetaan sementara pengisian kuesioner diperoleh hasil $66 \%$ peserta dikategorikan sebagai kelompok telah melakukan perencanaan dan pengelolaan keuangan, dan sisanya $34 \%$ dikategorikan kelompok ibu yang perlu bimbingan pelatihan dan pemahaman terkait pengelolaan keuangan. Pada tahapan ini, ditemukan hampir lebih dari sebagian peserta terdapat keraguan dalam memutuskan apakah aktivitas yang dilakukan tergolong dalam kebutuhan (needs) atau keinginan (wants). Tidak dipungkiri, pola konsumtif salah satunya yang terjadi pada masyarakat merupakan dampak yang dihadapi ketika teknologi makin mudah diadaptasi, sehingga terkadang menjadi suatu hal yang sulit untuk membedakan mana yang tergolong kebutuhan (needs) dan mana yang keinginan (wants), mana kebutuhan yang sifatnya primer, sekunder maupun tersier. (Mulyanti \& Nurdin, 2018).

Tahapan berikutnya, kedua kelompok peserta melakukan simulasi pemeriksaan kondisi keuangannya (Gambar 4) dengan menuliskan nilai nominal penghasilan yang diperoleh, serta jumlah alokasi pengeluaran dana yang selama ini dilakukan pada kertas kerja penilaian, dimana pengeluaran dana dikategorikan berdasarkan golongan apakah termasuk dalam jenis kebutuhan, keinginan atau investasi (menabung).

Tabel 2. Hasil Skor Keseimbangan Dana

\begin{tabular}{|l|c|c|}
\hline \multicolumn{1}{|c|}{ Kriteria Hasil Skor } & \multicolumn{2}{c|}{ Peserta } \\
\cline { 2 - 3 } & Grup 1 & Grup 2 \\
\hline Menabung (20\%) & - & 2 \\
\hline 0-5\% (kurang nabung) & 2 & - \\
\hline 6-12\% (penabung solid) & 1 & 1 \\
\hline Keinginan (30\%) & 6 & 4 \\
\hline$<20 \%$ (pekerja keras) & 2 & 2 \\
\hline 20-30\% (seimbang) & & \\
\hline$>30 \%$ (boros) & 3 & - \\
\hline Kebutuhan (50\%) & 4 & 3 \\
\hline$<35 \%$ (aman) & 1 & 1 \\
\hline $35-50 \%$ (seimbang) & $\mathbf{1 9}$ & $\mathbf{1 3}$ \\
\hline$>50-65 \%$ (berbahaya) & &
\end{tabular}

Nilai nominal tersebut kemudian dihitung berdasarkan persentase guna mendapatkan nilai skor keseimbangan dana yang mengacu pada "formula keseimbangan dana": $50 \%$ untuk kebutuhan, 30\% untuk keinginan, dan 20\% untuk investasi. Hasil yang diperoleh tiap peserta pada kedua kelompok diperoleh nilai skor bervariasi dengan narasi penjelasannya (Tabel 2).

Saat peserta mengisi kertas kerja penilaian kondisi keuangan, dibutuhkan komitmen kejujuran, dukungan komunikasi, diskusi dan kerjasama antar anggota dalam suatu keluarga untuk mengimplementasikan rencana anggaran yang telah dibuat dan disepakati bersama yang 
155 Pelatihan Pengelolaan Keuangan bagi Ibu PKK Kelurahan Bintara Jaya, Bekasi Barat- Triana Yuniati, Murti Wijayanti, Tutiek Yoganingsih, Budi Indrawati

DOI: https://doi.org/10.31004/abdidas.v2i1.234

meminimalisir kemungkinan terjadinya kesulitan keuangan yang lebih besar. Meski ditemukan hambatan pengelolaan keuangan pada peserta yang termasuk dalam golongan mampu mengelola keuangan, beberapa menyatakan kesulitan dalam mengklasifikasikan kategori alokasi dana untuk kebutuhan ataupun keinginan, di samping perlunya dilakukan monitoring dan evaluasi dari anggaran yang telah dibuat dan disepakati sebelumnya (Faridawati \& Silvy, 2019).

Berdasarkan tabel 2 kriteria hasil skor keseimbangan dana, dihasilkan $75 \%$ peserta mampu mengelola ketidakseimbangan dalam pengelolaan dana keuangan keluarga. Hambatan yang dialami selain pola hidup konsumerisme, kurang paham terhadap informasi adanya instrumen investasi yang menguntungkan dan persiapan masa pensiun yang kurang memadai, diatasi dengan penyuluhan materi dari tim narasumber untuk mensosialisasikan beberapa alternatif jenis instrumen keuangan negara. Beberapa solusi yang ditawarkan kepada ibu rumah tangga atas permasalahan keuangan yang dihadapi, diantaranya membiasakan melakukan pencatatan atas pemasukan dan pengeluaran baik rutin maupun non rutin, penyusunan anggaran belanja rumah tangga, dan melatih diri untuk tetap melakukan edukasi pentingnya kegiatan menabung dan investasi (Marviana et.al., 2020).

Peserta yang pengelolaan keuangannya masih belum sesuai dengan koridor formula keseimbangan dana, pada sesi diskusi tanya jawab, alasan yang disampaikan adalah kurangnya pemahaman tentang perencanaan keuangan. Pernyataan ini sejalan dengan penelitian yang menguji pengaruh tingkat kesadaran masyarakat terhadap kesejahteraan perencanaan keuangan keluarga (Wulandari \& Sutjiati, 2014).

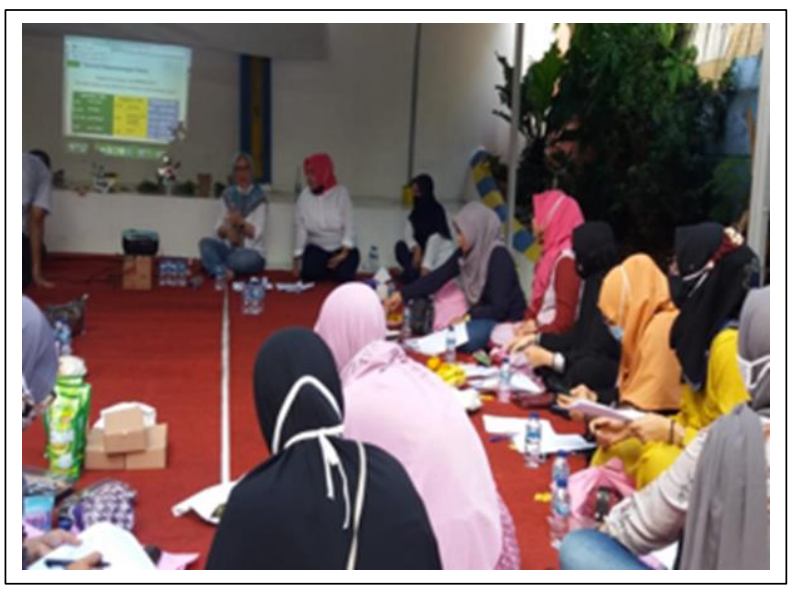

Gambar 4. Edukasi Pelatihan

\section{SIMPULAN}

Kegiatan pelatihan pengelolaan keuangan sederhana pada kelompok ibu-ibu PKK di RW. 014 Kelurahan Bintara Jaya, Kecamatan Bekasi Barat ini, menyimpulkan hasil sebagai berikut :

1. Terjadi peningkatan pemahaman peserta sebesar 9\% pada kelompok 1 kategori peserta yang telah melakukan aktivitas perencanaan dan pengelolaan dana keuangan keluarga sesuai dengan koridor formula keseimbangan dana, dan penurunan 9\% pada kelompok peserta kategori 2 yang perlu bimbingan pelatihan dan pemahaman terkait pengelolaan keuangan. Persentase angka peningkatan dan penurunan tersebut merupakan perbandingan antara pemahaman peserta pada awal pemetaan menggunakan kuesioner dengan hasil pelatihan menggunakan simulasi kertas kerja. 
156 Pelatihan Pengelolaan Keuangan bagi Ibu PKK Kelurahan Bintara Jaya, Bekasi Barat- Triana Yuniati, Murti Wijayanti, Tutiek Yoganingsih, Budi Indrawati

DOI: https://doi.org/10.31004/abdidas.v2i1.234

2. Penggunaan simulasi kertas kerja sederhana sebagai alat perencanaan anggaran keuangan sangat berguna untuk introspeksi aktivitas kegiatan pengelolaan dana dan sangat membantu untuk diterapkan oleh masyarakat siapapun di berbagai lapisan untuk mengantisipasi pola hidup konsumtif yang terkadang tidak disadari dilakukan, tanpa melakukan penyesuaian terhadap penghasilan yang dimiliki. Harapannya, modul dalam bentuk kertas kerja yang digunakan pada praktik pelatihan dapat dijadikan pedoman melakukan pengelolaan keuangan yang lebih baik dan lebih efektif. Pada akhirnya sejahteranya suatu masyarakat dikarenakan mampu memilah antara kebutuhan dan keinginan, di samping mampu menyisihkan penghasilan tersebut untuk dialokasikan sebagai tabungan darurat dan persiapan menjalani masa pensiun.

\section{DAFTAR PUSTAKA}

Faridawati, R., \& Silvy, M. (2019). Pengaruh niat berperilaku dan kecerdasan spiritual terhadap pengelolaan keuangan keluarga. Journal of Business \& Banking. https://doi.org/10.14414/jbb.v7i1.1465

Handayani, N. (2013). Cara Sederhana Mengelola Keuangan Keluarga. Jurnal Keluarga Sehat Sejahtera, 11(2), 29-34.

Hidayah, N. (2018). ALOKASI PENDAPATAN DAN LITERASI KEUANGAN Studi Kasus pada Desa Sidomukti Kecamatan Plaosan Kabupaten Magetan. KEBERLANJUTAN, 3(1), 825-856. https://doi.org/10.32493/keberlanjutan.v3i1.y 2018.p825-856

Marviana, R. D., Nurhayati, N., \& Asnawi, M. (2020). PKM Pengelolaan Keuangan Keluarga Bagi Ibu-Ibu Rumah Tangga
Kelompok Menabung Seroja Di Desa Tapak Kuda. RESWARA: Jurnal Pengabdian Kepada Masyarakat, 1(2), 155-161.

Mulyanti, D., \& Nurdin, S. (2018). Pelatihan Perencanaan Keuangan Keluarga Bagi IbuIbu PKK Kecamatan Cimenyan Kabupaten Bandung. Jurnal Abdimas BSI: Jurnal Pengabdian Kepada Masyarakat, 1(2), 259267.

Senduk, S. (2009). Seri Perencanaan Keuangan, Mengelola Keuangan Keluarga. PT. Elex Media Komputindo. Jakarta.

Warren, Amelia., \& Tyagi, AW. (2005). All Your Worth : The Ultimate Lifetime Money Plan, Free Press e-book. New York.

Wulandari, F. A., \& Sutjiati, R. (2014). Pengaruh Tingkat Kesadaran Masyarakat Dalam Perencanaan Keuangan Keluarga Terhadap Kesejahteraan (Studi pada Warga Komplek BCP, Jatinangor). Jurnal Siasat Bisnis, 18(1), 21-31.

Yushita, A. N. (2017). PENTINGNYA LITERASI KEUANGAN BAGI PENGELOLAAN KEUANGAN PRIBADI. Nominal, Barometer Riset Akuntansi Dan Manajemen. https://doi.org/10.21831/nominal.v6i1.14330 